\title{
Is Sticky Price Adjustment Important for Output Fluctuations?*
}

\author{
John W. Keating a,d \\ jkeating@ku.edu
}

and

\author{
Isaac K. Kanyama ${ }^{\text {b,c }}$ \\ ikanyama@uj.ac.za
}

a: University of Kansas, Department of Economics, Lawrence, KS 66045.

b: University of Johannesburg, Department of Economics and Econometrics, Johannesburg, South Africa.

c: Université de Kinshasa, Département d'Economie, Kinshasa XI, RDC.

d: Corresponding author.

April 24, 2012

Key Words: sticky price adjustment, aggregate supply and demand, moving average representation, identification restrictions

\begin{abstract}
We find that shocks with no immediate effect on the price level explain essentially all short-run variance of aggregate output while shocks that immediately affect price explain virtually none of that variance. Similar findings are obtained with aggregate, sectoral and industry-level data, both seasonally adjusted and not seasonally adjusted. With aggregate data, shocks that immediately raise the price level eventually cause output to fall while shocks that affect price with a lag immediately raise output and eventually cause the price level to rise. These responses combined with the variance decompositions suggest the short-run aggregate supply curve is nearly horizontal and the aggregate demand curve is nearly vertical. A statistical model that identifies shocks that don't affect prices for at least two months is also developed. Shocks with the slowest effect on prices explain essentially all of the short-run output variance in almost all cases. This robust finding is inconsistent with theories in which prices adjust rapidly to clear markets.
\end{abstract}

\footnotetext{
* We thank Bill Barnett, Jim Bullard, Steve Fazzari, Bill Gavin, Ken Matheny, Larry Meyer, Steve Russell, Chris Sims and seminar participants at the Board of Governors of the Federal Reserve, the Federal Reserve Bank of Kansas City, Washington University, Virginia Tech, Missouri, LSU, Kansas, Illinois at Chicago, Colorado at Denver, the Midwest Macroeconomics Conference at Notre Dame and the Society of Economic Dynamics and Control Meetings in Mexico City for helpful suggestions on preliminary drafts of this paper. Thanks to Ben Herzon for help in obtaining data in an earlier version of this paper. Naturally, we assume full responsibility for any errors and omissions.
} 


\section{(1) Introduction}

A cornerstone of Keynesian explanations of the business cycle is that nominal prices fail to adjust promptly to clear markets. The first generation of sticky price theories simply asserted that prices responded with an arbitrary lag, an ad hoc assumption that yielded disequilibrium in the aggregate economy. New Keynesian models have since been constructed with the goal to provide a more rigorous microfoundation for sticky prices. ${ }^{1}$ And sticky price adjustment may even be an equilibrium outcome under certain conditions, see Farmer (2000, 1992), for example.

Sticky price theories have often been justified by casual observation. However, some empirical research has addressed questions about how fast market prices adjust. Seminal studies in this area include Mills (1927) and Stigler and Kindahl (1970). More recent work by Carlton (1986), Cecchetti (1986), Blinder (1994), Kashyap (1995), Blinder et. al. (1997), Levy et. al. (1997), Bils and Klenow (2004) and Willis (2006) sheds additional light on these concerns.

In a somewhat radical departure from standard econometric practice, Blinder (1994) and Blinder et. al. (1997) question firms about how prices are determined. This research attempts to discover what motivates a firm to sometimes hold its price fixed, what induces firms to change prices and how pervasive sticky price adjustment is in a modern industrial economy. An important conclusion from that research is almost four-fifths of Gross Domestic Product (GDP) in the United States is re-priced less than once every three months. ${ }^{2}$ While some may interpret this finding as strong support for the hypothesis that sticky prices play a key role in output determination, that conclusion is premature.

Ohanian, Stockman and Kilian (1995) is one of the first papers to build a two-sector model where the price in one sector does not respond contemporaneously to new information while price adjusts immediately to clear the other sector. ${ }^{3}$ This modeling strategy is consistent with Blinder's finding that some firms rapidly change their prices while other firms are slow to do so. Ohanian et. al. find that the effect of money on aggregate real output depends on how big the sticky price sector is relative to the flexible price sector and also on the values of certain structural parameters. They also show that it is 
theoretically possible for flexible-price sectors to adjust in such a way that the aggregate economy behaves essentially like a flexible price system even if sticky price adjustment is fairly common. Barsky, House and Kimball (2007) obtain a similar result for an economy in which prices adjust rapidly for durable goods but are sticky for nondurables. Caplin and Spulber (1987) present a different model that under certain conditions yields the same outcome. These findings call for empirical studies to determine whether or not sticky price adjustment is important for output fluctuations.

This paper uses vector autoregressions to construct empirical measures of the amount of output fluctuation associated with different types of price co-movement. Section 2 presents a bivariate statistical model that identifies shocks that affect the price-level contemporaneously and shocks that do not have an immediate effect on prices. The latter of these two types of shocks is used in an attempt to quantify the role of sticky prices in output fluctuations. $\mathrm{Ng}$ (2003) uses a similar approach to study the importance of sticky prices for fluctuations in real exchange rates. Estimates of the output variance associated with these shocks are presented in the third section using a variety of data for the United States. With aggregate data, shocks which have no immediate effect on the price level explain almost all the variance of output in the short run. A similar finding is obtained in models with sectoral and industry-level data using either seasonally adjusted or not seasonally adjusted series. When we examine the impulse responses with aggregate data we find the shocks that immediately raise the price level eventually cause a significant decline in output, while the shocks that affect price with a lag raise output immediately and eventually cause the price level to rise. Our results with aggregate data suggest the economy behaves like a simple textbook model in which the short-run aggregate supply curve is very flat and the aggregate demand curve nearly vertical.

Section 4 develops a statistical model based on dynamic restrictions. We identify three types of shocks: Shocks that have no effect on price for two months, shocks that don't affect price for one month and shocks that contemporaneously affect the price level. This model finds that shocks which don't affect the price level for two months are much more important for aggregate output over the short-run and at business cycle frequencies than the other two shocks combined. Our general finding is that shocks with 
the slowest effect on price are the dominant factor in short-run output fluctuations.

Section 5 concludes the paper with a discussion of the implications from our empirical results. Overall, this paper's findings are irreconcilable with flexible price adjustment and therefore provide evidence that sticky price adjustment plays a quantitatively significant role in output fluctuations. However, the finding that movements in output and price are nearly orthogonal for a substantial amount of time is difficult to reconcile with standard models of sticky price adjustment.

\section{(2) A Bivariate Empirical Model}

Most of our estimates are based on a model that attributes output fluctuations to two shocks, one that is associated with contemporaneous movement in the price level and one that is not. The logarithm of a price series (P) and the logarithm of a measure of real output (y) are used in this bivariate decomposition, written as:

$$
\begin{aligned}
& P_{t}=\Theta_{p \varepsilon}(\mathrm{L}) \varepsilon_{t}+\Theta_{p \gamma}(\mathrm{L}) \gamma_{t} \\
& y_{t}=\Theta_{y \varepsilon}(\mathrm{L}) \varepsilon_{t}+\Theta_{y \gamma}(\mathrm{L}) \gamma_{t}
\end{aligned}
$$

where $\Theta_{i j}(\mathrm{~L})=\sum_{k=0}^{\infty} \Theta_{k i j} \mathrm{~L}^{k} \quad$ for $\mathrm{i}=\mathrm{p}, \mathrm{y}$ and $\mathrm{j}=\varepsilon, \gamma$

are lag polynomials from the moving average representation of this empirical model. The stochastic shocks, $\varepsilon_{\mathrm{t}}$ and $\gamma_{\mathrm{t}}$, are assumed uncorrelated with one another and serially uncorrelated. Without loss of generality, the empirical model may include deterministic elements which have been omitted for analytical convenience from (1) and (2). All estimated VARs will have a constant in each equation. We identify $\varepsilon_{\mathrm{t}}$ as a shock to the price level that may have an immediate effect on output. We identify $\gamma_{\mathrm{t}}$ as the shock to output that has no contemporaneous price level effect by setting $\Theta_{0 p \gamma}=0$. This model requires no restrictions on the dynamic responses of variables to shocks, except that the stochastic process is invertible. A Cholesky decomposition of the covariance matrix for VAR residuals with price placed ahead of output in the recursive ordering identifies this model. Consequently, $\varepsilon_{t}$ is the one-step forecast error for price, or equivalently the innovation to the price level. 
The idea is to decompose output fluctuations into a component associated with contemporaneous price movements $(\varepsilon)$ and another that is associated with no contemporaneous movement in prices $(\gamma)$. Our initial intent was to use the output variance explained by $\gamma$ shocks to get a rough measure of the importance of sticky price adjustment for output fluctuations. We did not anticipate the many features of the variance decompositions that would be so striking and robust to various kinds of data.

It is important to note that this bivariate statistical model can also be given a structural interpretation. Suppose the macroeconomy is characterized by an aggregate demand and supply structure in which the short-run aggregate supply curve is perfectly flat. A flat short-run supply curve implies that the innovations to the price level, $\varepsilon$, are shocks to the short-run aggregate supply curve and the shocks to output that have no contemporaneous effect on prices, $\gamma$, are attributable to shifts in the aggregate demand

curve. ${ }^{4}$ We shall see that the impulse responses and variance decompositions from aggregate data are consistent with a version of that simple structural model.

\section{(3) Empirical Results from the Bivariate Model}

We select VAR specifications using Akaike's information criterion, and then construct the bivariate decomposition from Section 2. First, we use quarterly U.S. real GDP and the GDP deflator in the model. Potential data problems suggest a sequence of specifications in which data available at higherfrequency and data from different sectors and different industries are examined, in seasonally adjusted and not seasonally adjusted form. One of our main findings is an overwhelming tendency for movements in output and price to be virtually orthogonal for a significant period of time.

\section{(3.1) Gross Domestic Product Data}

The first bivariate estimates use quarterly aggregate data, measuring output by real chainweighted GDP and the price level by the chain-weighted GDP deflator. ${ }^{5}$ With a maximum number of lags set at 16 quarters, the Akaike information criterion selects a VAR model with 4 lags. Series from the first quarter of 1947 to the second quarter of 2010 are used to estimate this model. Table 1 reports the variance 
decomposition along with standard errors obtained from 5000 bootstrap replications of the model. ${ }^{6}$ By construction, $\gamma$ has no immediate effect on the price level so $\varepsilon$ initially explains all of the price variance. But even after two years $\gamma$ shocks explain a statistically insignificant 2 percent of the price variance. In fact, the price variance explained by this shock is only significant at very long horizons. After 10 years the variance explained by $\gamma$ is 25 percent and significant at the 10 percent level. After 25 years this shock explains about half the price variance. It takes an extremely long time before this shock explains either a large or a statistically significant amount of price variance.

Even though the model permits price level innovations to have an immediate effect on output, they explain virtually none of the output variance in the short run. This finding results to a large extent because output and the price level innovations in the VAR are almost uncorrelated. ${ }^{7}$ In fact, price innovations never explain a statistically significant portion of GDP's variance, and the point estimate is essentially zero for about 2 years. Consequently, output shocks that have no contemporaneous effect on the price level are the dominant source of aggregate output fluctuations, explaining essentially all of output's variance for the first two years and at least 92 percent of output's variance at each point in the variance decomposition. Also, since this shock explains virtually none of the variance of the price for about one year the variance decompositions indicate that movements in the price level and output are essentially independent of one another for at least a year. This is a surprisingly long time given the intuition from most economic models that prices and output adjust together in response to economic shocks.

Figure 1 provides dynamic responses of each variable to each shock. Each impulse response plots the point estimate with a solid line and encloses the 90 percent confidence region with dashed lines. Confidence bounds are generated from the same bootstrap simulations used to construct standard errors for variance decompositions. The price innovation immediately causes a statistically significant rise in the price level. Initially output oscillates around zero and is statistically insignificant, but eventually it begins a gradual decline and at its most negative response is nearly statistically significant. The movement of price and output in opposite directions suggests aggregate supply is the dominant source of $\varepsilon$ shocks. At 
long horizons price and output responses to $\varepsilon$ are positive, but these effects are small and far from being statistically significant. The $\gamma$ shock causes a gradual increase in price, and this positive response quickly becomes statistically significant. The output response to this shock is always positive and significant with the peak response occurring after 3 quarters. These price and output responses suggest aggregate demand is the source of this shock. Hence, these responses are consistent with a flat short-run aggregate supply curve, the simple structural model that one might use to motivate the statistical model.

Virtually all the short-run price variance is explained by $\varepsilon$ and virtually all the short-run output variance is explained by $\gamma$. These variance decompositions suggest that the short-run aggregate supply is

nearly flat the aggregate demand curve is nearly vertical, at least in the short run. ${ }^{8}$ While one may object to this structural interpretation of the statistical model, the qualitative nature of these impulse responses suggests the shocks that are slow to cause a significant change in the price level are primarily associated with aggregate demand and shocks that have an immediate effect on price are primarily from aggregate supply. The hump-shaped response pattern of output to $\gamma$ is also consistent with some views about the dynamic response of output to aggregate demand. ${ }^{9}$ If those shocks are primarily from aggregate demand, the variance decompositions suggest that aggregate demand shocks are also the dominant source of longrun movements in output. That is not a feature of some macro models, particularly not for the textbook model of aggregate demand and supply typically taught to undergraduates. However, there are a number of structural models that can sometimes generate a permanent positive output effect from increased aggregate demand. Examples of that include hysteresis in the labor market, coordination failure and nonsuperneutrality of money.

\section{(3.2) Are the results obtained because of temporal aggregation bias?}

The model with GDP finds the shocks that have no contemporaneous effect on the price level are most important for output fluctuations. One concern raised by the use of GDP data is the possibility that quarterly time series may smooth out high-frequency co-movement between aggregate output and the price level. Total Industrial Production (IP) provides a measure of aggregate output that is available at 
monthly intervals. The Producer Price Index (PPI) appears at first to be a proper choice for the monthly price measure because it is well-matched with components of Industrial Production. However, the PPI has limitations, and for the purposes of this paper, the most important problem is that the PPI may be an inadequate measure of transactions prices. Wynne (1995,p.2), for example, argues that price data reported by producers may not be accurate "because of fears the data may be used in antitrust litigation or fall into the hands of competitors." The Consumer Price Index (CPI) data provides more reliable measures of transactions prices because the Bureau of Labor Statistics constructs these series by periodically collecting posted prices from a large number of suppliers.

Seasonally adjusted measures of Total Industrial Production and the CPI for All Items for Urban Consumers are used to estimate the aggregate model with monthly data. All data available up to August 2010 are used in this VAR and all subsequent VAR models so that sample periods end at roughly the same time as our model with quarterly aggregate series. The Appendix describes the monthly price and output series and the starting date for each bivariate model. The number of lags for each model, chosen by the Akaike information criterion with maximum lags of 48 months, is also provided in this Appendix.

The decomposition for monthly aggregate data is reported in the first column of Table 2 and the impulse responses are in Figure 2. From this point onward, each table and figure uses months instead of quarters. There are two reasons why we report the variance results for only $\gamma$ in the table: First, it is easy to subtract this variance from 100 percent to calculate the amount of variance attributable to price innovations. Second, any VAR model with two shocks obtains numerically identical standard errors for the variance explained by either shock at each point in a variable's decomposition. Table 1 clearly illustrates how results for a single shock contain all information in the bivariate model's decomposition.

The results with aggregate monthly data essentially replicate the results obtained with quarterly aggregate data. Shocks with no contemporaneous effect on the price level are once again the dominant factor in output fluctuations. The monthly model's variance decomposition is remarkably similar to the one from quarterly GDP data. The shock that has no effect on price for the first month explains essentially all of the output variance out to 12 months and essentially none of the price variance out to 9 months. 
Impulse responses to this model are broadly similar to the responses from GDP data. ${ }^{10}$ This output response is hump shaped with a peak at 12 months, a little later than was observed with quarterly data, but still fairly close. One notable difference is that the negative output response to a price innovation has a substantial period over which the effect is statistically significant. This strengthens the case for interpreting $\varepsilon$ in the aggregate models as an aggregate supply shock. All the key implications are robust to the use of higher frequency aggregate data. Thus these results are also consistent with a model that has flat short-run aggregate supply and vertical aggregate demand.

\section{(3.3) Are the results obtained because of sectoral aggregation bias?}

One problem with using Total Industrial Production and the CPI for All Items is that these data do not cover precisely the same sectors of the economy. For example, the CPI for All Items includes prices for services and the rental cost of existing housing, neither of which pertain to current industrial production. ${ }^{11}$ And Total IP includes equipment, materials and intermediate goods that are sold to establishments instead of consumers. However, results from these aggregate series are essentially the same as results obtained with a model that uses Consumer Goods output and the CPI for Commodities, data representing the largest component of Industrial Production that has a corresponding CPI measure.

A key empirical finding with aggregate data is that innovations to price and output are nearly uncorrelated. Interpretation of this finding is complicated by the possibility that the aggregate supply and aggregate demand equations may coincidentally yield uncorrelated innovations in aggregate data. To illustrate this point, assume $\mathrm{e}_{\mathrm{pt}}$ and $\mathrm{e}_{\mathrm{yt}}$ are the innovations to price and real output from a bivariate VAR model with aggregate data. Suppose the short-run structure consists of the following two equations:

$$
\begin{aligned}
& \text { Aggregate Supply: } e_{p t}=a_{s} e_{y t}+\tau_{s t} \\
& \text { Aggregate Demand: } e_{y t}=-a_{d} e_{p t}+\tau_{d t}
\end{aligned}
$$

where $a_{i}$ is a non-negative parameter, $\tau_{i t}$ is a structural shock and $\sigma_{i}$ is a shock standard error, for $i=s, d$. Assuming the aggregate demand and supply shocks are uncorrelated, it is easy to solve for the covariance 
between the two innovations:

$$
\mathrm{Ee}_{\mathrm{pt}} \mathrm{e}_{\mathrm{yt}}=\frac{\mathrm{a}_{\mathrm{s}} \sigma_{\mathrm{d}}^{2}-\mathrm{a}_{\mathrm{d}} \sigma_{\mathrm{s}}^{2}}{\left(1+\mathrm{a}_{\mathrm{s}} \mathrm{a}_{\mathrm{d}}\right)}
$$

When $\mathrm{a}_{\mathrm{d}}$ and $\mathrm{a}_{\mathrm{s}}$ are both equal to zero this covariance is zero. In other words, a flat aggregate supply curve, $\mathrm{a}_{\mathrm{s}}=0$, and a vertical aggregate demand curve, $\mathrm{a}_{\mathrm{s}}=0$, would yield uncorrelated innovations to price and output.

A flat short-run aggregate supply curve means that prices do not respond to current demand conditions. There are many ways one might motivate such behavior. For example, if a firm has imperfect information about whether a change in demand is temporary or permanent and there are costs to changing prices, ${ }^{12}$ then when a firm observes an increase in demand it may be optimal to delay raising prices until the firm is more certain that higher demand will persist. A vertical aggregate demand curve is also easy to justify. The simplest way is if the interest elasticity of spending is zero, but there are more elaborate and possibly more appealing ways for a vertical aggregate demand curve to arise. ${ }^{13}$

However, flat short-run aggregate supply and vertical aggregate demand is not the only possible explanation. If all the parameters are non-zero, the covariance between price and output innovations will be zero when $\frac{\mathrm{a}_{d}}{a_{s}}=\frac{\sigma_{d}^{2}}{\sigma_{\mathrm{s}}^{2}}$. Therefore, the finding that innovations to aggregate price and output are virtually uncorrelated does not prove that the short-run aggregate supply curve is flat.

Another potential problem with aggregate series is they combine output and price data from a variety of sectors. These sectors can produce very different types of goods and services, and they may be characterized by different types of market structure. One cannot rule out the possibility that short-run movements in output and price are correlated in sectoral data and that this correlation varies across sectors in such a way that high frequency movements in aggregate measures of price and output happen to be uncorrelated. The possibility of a hidden contemporaneous relationship between price and output in aggregate data suggests that sectoral price and output data should be used in the bivariate model. Clearly, the statistical model is no longer interpretable as an aggregate demand and supply model when we depart 
from the use of aggregate data. However, it will be interesting to see if any patterns observed in aggregate output and price level data are also observed in sectoral data.

Total Industrial Production can be separated into Market Groups. For compatibility with CPI price measures, we focus on groups of consumer goods. Foods, Tobacco Products, Consumer Clothing, Consumer Energy Products, Consumer Autos, Consumer Trucks and Other Consumer Durables are found to have appropriate CPI measures. ${ }^{14}$ The first four groups are Consumer Nondurables and the last three are Consumer Durables. The Other Consumer Durables category includes appliances, televisions, air conditioners, carpeting, furniture, and miscellaneous home goods. ${ }^{15}$

Table 2 reports variance decompositions for these 7 sectors. Essentially all the variance of each sector's output over the first 3 months is associated with shocks that have no contemporaneous effect on the price level. Except for Tobacco and Other Durables, we can't reject the hypothesis that this shock explains all the output variance out to 6 months. In fact, this shock explains most of the variance at any point, again with the exception of Other Durables and Tobacco. The result is even stronger for Autos, Clothing, Energy and Food where we can't reject the hypothesis that the shock with no immediate effect on price explains all the variance of output at each point in the decomposition.

Shocks that have no contemporaneous price effect explain almost none of the price variance for the first year for each variable. At longer horizons these shocks explain most of the price variance for Clothing, Energy and Trucks. In contrast, essentially all the variance of price is explained by price innovations for Autos, Other Durables and Tobacco. While there is some variation at longer horizons, the sectoral and aggregate data obtain similar results. In the short run, output and price movements are largely unrelated to one another in these durable and non-durable goods sectors. ${ }^{16}$

An advantage of Market Group data is that these product measures encompass most of the currently produced goods sold to consumers. Unfortunately, some of these groups aggregate over a wide variety of different products. Therefore, some may be concerned that an aggregation bias obfuscates important short-run relationships between price and output in sectoral data. Consequently, we sought 
measures of production for industries at the lowest level of aggregation for which compatible CPI measures can be obtained. We separate these industries into non-food and food categories. Estimates for 2 non-food industries are in Table 3 and the estimates for 8 food industries are in Table 4. The empirical results for Automotive Gasoline, Furniture, Poultry, Butter, Cheese, Dairy Products, Beer and Soft Drinks support the main findings from the previous models: Shocks which have no contemporaneous price effect explain essentially all of the short-run output variance and essentially none of the short-run price variance. The two exceptions are Beef and Pork where price innovations explain 17\% and 8\%, respectively of the output variance after one month and both are statistically significant. But even in these two cases the shocks that have no contemporaneous price effect explain at least 77 percent of the output variance over the course of a year. Hence, shocks which have no immediate effect on price are the dominant factor in short-run output fluctuations in every case, and in most cases we fail to reject the hypothesis that they explain all the output variance for a substantial period of time.

The impulse responses from sectoral and industry-level data are not reported here because they do not yield any noteworthy patterns. Furthermore, impulse responses are not important for our purposes because these models are designed to quantify the amount of output variation associated with short-run price movements, not to identify structural sources of shocks to various markets. A few of these responses are similar to results obtained with aggregate data, but in most cases the responses with sectoral and industry data are significantly different. This variation in responses is almost certainly related to markets having different responsiveness to various types of aggregate and market-specific shocks. ${ }^{17}$

Recall we previously showed how price and output innovations in aggregate data could be uncorrelated because of a particular setting of non-zero structural parameters, not necessarily a consequence of sticky prices and a flat short-run aggregate supply curve. Should we be concerned that the findings with sectoral and industry-level data could also be explained by a related argument? That hypothesis is highly improbable. It requires an amazing coincidence - many combinations of non-zero structural parameters that somehow yield no short-run co-movement between output and price. The most plausible explanation is that the variance decompositions from aggregate data are reflecting the 
relationship in the vast majority of markets.

\section{(3.4) Are the results obtained because of seasonal adjustment bias?}

VAR models up to this point have used seasonally adjusted data primarily because this transformation is more commonly used in empirical studies. But that leaves open a question: Could seasonal adjustment of data eliminate a high-frequency relationship between price and output? ${ }^{18}$ To address this question, we estimate each of the monthly VAR models with not seasonally adjusted data, using monthly dummy variables to allow for different seasonal means in price and output. Lag lengths are again chosen by Akaike's information criterion with 48 months selected as the upper bound on lags.

Variance decompositions from VAR models with not seasonally adjusted data are in Tables 5, 6 and 7. Table 5 reports the variance decompositions for Total Industrial Production and the 7 Market Groupings, Table 6 reports estimates from the 2 non-food industries and Table 7 contains results for the 8 food industries. Tables 5, 6 and 7 can be compared with results using seasonally adjusted data found in Tables 2, 3 and 4, respectively. The variance decompositions with not seasonally adjusted data are remarkably similar to results found with seasonally adjusted data. Shocks that have no contemporaneous effect on the price level explain virtually all the short-run variance of output for most of the models and only the Beef and Pork industries produce evidence that price innovations can explain a statistically significant amount of short-run output variance. The percentages are similar to what was found with seasonally adjusted data. Once again, shocks that have no contemporaneous price effect are the primary source of short-run output variation, and in most cases these shocks explain virtually all of the short-run output variance. $^{19}$

And price innovations still explain nearly all the short-run variance of price. Pork is the only industry in which we cannot reject the hypothesis that for 3 months all of the variance of price is explained by the price innovation. Otherwise, we obtain similar findings no matter if the data are seasonally adjusted or not. Output and price movements are statistically unrelated in the short run in almost all of our estimates, and even in those few exceptional cases the co-movement between output and 
price is surprisingly small.

\section{(3.5) Overview of the results from bivariate models}

Virtually all the short-run variance of real GDP is associated with shocks that have no effect on the price level in the short run. The same result holds for monthly data for the aggregate economy and for 7 large Market Groups. The data from a group of 10 industries is also supportive. Beef is the only industry in which a significant amount, both economically and in statistical terms, of output variance is explained by price innovations. In most other cases, we can't reject the hypothesis that none of the shortrun output variance is explained by price innovations.

There is very little evidence of co-movement between output and prices in the short run. According to the variance decompositions most, if not all, of short-run output fluctuations are associated with no contemporaneous change in the price level. Similarly, we find that prices don't react for some time to shocks that have no immediate effect on the price level. Only in one case, the Pork industry, do we find a statistically significant and sizable amount of price variance during the first 3 months explained by the shock that has no immediate effect on prices. The robust conclusion from this empirical exercise is that movements in output and the price level are typically orthogonal for a substantial period of time.

\section{(4) Identifying Shocks that have no Effect on the Price Level for Two Months}

Our last model uses dynamic restrictions to study the relationship between price and output fluctuations. We will identify shocks in aggregate data that do not affect the price level for two months, shocks that have no price effect for one month and shocks that contemporaneously influence the price level. The motivation is straightforward: If most prices are sticky for at least a few months, an assumption consistent with the evidence from Blinder's surveys and from Bils and Klenow's detailed analysis of BLS data, and if sticky price adjustment is important for aggregate fluctuations, then we expect shocks with no effect on the price level for two months to be the major factor for short-run output movements. To estimate a VAR model with three independent shocks, a third variable is required. We chose to include 
the Fed Funds interest rate, R, along with Total Industrial Production and the CPI for All Items, because interest rates are commonly used in empirical macro models and generally important in theoretical analysis. The empirical model is characterized by the following three equations:

$$
\begin{aligned}
& \mathrm{P}_{\mathrm{t}}=\Theta_{\mathrm{p} \varepsilon}(\mathrm{L}) \varepsilon_{\mathrm{t}}+\Theta_{\mathrm{p} \gamma}(\mathrm{L}) \gamma_{\mathrm{t}}+\Theta_{\mathrm{p} \phi}(\mathrm{L}) \phi_{\mathrm{t}} \\
& \mathrm{y}_{\mathrm{t}}=\Theta_{\mathrm{y} \varepsilon}(\mathrm{L}) \varepsilon_{\mathrm{t}}+\Theta_{\mathrm{y} \gamma}(\mathrm{L}) \gamma_{\mathrm{t}}+\Theta_{\mathrm{y} \phi}(\mathrm{L}) \phi_{\mathrm{t}} \\
& \mathrm{R}_{\mathrm{t}}=\Theta_{\mathrm{r} \varepsilon}(\mathrm{L}) \varepsilon_{\mathrm{t}}+\Theta_{\mathrm{r} \gamma}(\mathrm{L}) \gamma_{\mathrm{t}}+\Theta_{\mathrm{r} \phi}(\mathrm{L}) \phi_{\mathrm{t}}
\end{aligned}
$$

where the restrictions: $\Theta_{0 \mathrm{p} \phi}=\Theta_{1 \mathrm{p} \phi}=0$

identify $\phi_{t}$ as a shock that has no effect on the price level for two months. As before, the shocks are assumed to be uncorrelated with one another. It is convenient to write the moving average representation of the model as:

$$
\mathrm{X}_{\mathrm{t}}=\Theta(\mathrm{L}) \tau_{\mathrm{t}}
$$

where $\mathrm{x}=(\mathrm{P}, \mathrm{y}, \mathrm{R})^{\prime}$, and the parameters in $\Theta(\mathrm{L})$ are taken directly from (4), (5) and (6). Pre-multiply (8) by $\Theta(L)^{-1}$, and then pre-multiply by $\Theta_{0}$ to obtain the VAR representation:

$$
\begin{array}{cc} 
& \beta(\mathrm{L}) \mathrm{x}_{\mathrm{t}}=\mathrm{e}_{\mathrm{t}} \\
\text { where } & \beta(\mathrm{L})=\Theta_{0} \Theta(\mathrm{L})^{-1} \\
\text { and } & \mathrm{e}_{\mathrm{t}}=\Theta_{0} \varepsilon_{\mathrm{t}}
\end{array}
$$

by construction. Let $\beta(L)=I-\beta_{1} L-\beta_{2} L^{2}-\cdots$ and $\Theta(L)=\Theta_{0}+\Theta_{1} L+\Theta_{2} L^{2}+\cdots$, where $\Theta_{i}$ and $\beta_{i}$ are $3 \times 3$ matrices of the parameters from the moving average representation and from the VAR, respectively. Equation (10) provides an infinite number of identities that map parameters from the moving average representation into the VAR coefficients. This can be seen by post-multiplying equation

(10) by $\Theta(L)$ :

And using the previous definitions:

$$
\beta(\mathrm{L}) \Theta(\mathrm{L})=\Theta_{0}
$$

$$
\left(\mathrm{I}-\beta_{1} L-\beta_{2} L^{2}-\cdots\right)\left(\Theta_{0}+\Theta_{1} L+\Theta_{2} L^{2}+\cdots\right)=\Theta_{0},
$$

it is easy to solve for each $\Theta_{\mathrm{i}}$ as a function of VAR coefficients and $\Theta_{0}$ by equating the coefficients on 
each lag polynomial. For example, the coefficients on L raised to the power one imply that:

$$
\Theta_{1}=\beta_{1} \Theta_{0}
$$

This matrix expression provides nine individual equations. The one associated with the first row and the third column in (11) is:

$$
\Theta_{1 \mathrm{p} \phi}=\beta_{1 \mathrm{pp}} \Theta_{0 \mathrm{p} \phi}+\beta_{1 \mathrm{py}} \Theta_{0 \mathrm{y} \phi}+\beta_{1 \mathrm{pr}} \Theta_{0 \mathrm{r} \phi}
$$

Given the restrictions from (7) that identify $\phi_{t}$ and normalizing the effects of that shock on the interest rate $^{20}$ by setting $\Theta_{0 \mathrm{r} \phi}=1$, equation (12) yields:

$$
\Theta_{0 \mathrm{y} \phi}=\frac{-\beta_{1 \mathrm{pr}}}{\beta_{1 \mathrm{py}}} .
$$

Equation (13) and the restriction that $\Theta_{0 \mathrm{p} \phi}=0$ constrain $\phi_{\mathrm{t}}$ to have no effect on the price level until two months have passed. To identify $\gamma_{\mathrm{t}}$ as a shock that cannot affect the price level for one month, we set: $\Theta_{0 \mathrm{p} \gamma}=0$, which is precisely the same restriction used in the bivariate models. Hence, this model contains two shocks which have no contemporaneous price effect, one which can not affect the price level for one month and the other which can not affect the price level for at least two months. Given these restrictions, all remaining parameters in $\Theta_{0}$ are estimated. Once again, output effects from an innovation to the price level are unconstrained.

Variance decompositions for this model are in Table 8. Shocks with no price effect for two months are the dominant source of output variance over the first year. These shocks initially explain $89 \%$ of output's variance, and even after 12 months they still account for $71 \%$ of that variance. The price and output responses also suggest that aggregate demand is the primary source of shocks which have no effect on price for at least two months. ${ }^{21}$ The short-run effects of the $\gamma$ shocks observed in bivariate models with aggregate data have now been transferred to the $\phi$ shocks in this trivariate model. This result is consistent with our prior that sticky prices are important for output fluctuations and that most prices in the economy are sticky for at least two months. 


\section{(6) Concluding Comments}

A principle finding from our bivariate models is that short-run output variance is primarily associated with shocks that have no contemporaneous effect on the price level. In general, shocks that have the slowest effect on the price level are the dominant source of short-run output fluctuations. This evidence provides strong support for the hypothesis that sticky price adjustment is a major factor in output fluctuations.

We also obtain impulse responses with aggregate data in which the shocks with a delayed effect on the price level behave like aggregate demand and the shocks that have an immediate effect on the price level behave like aggregate supply. These impulse responses combined with the finding that short-run movements in output and price level are nearly orthogonal to one another suggest that the aggregate supply curve is nearly flat and aggregate demand is very steep.

Proponents of flexible price adjustment may wish to claim that a nominal price adjusts within the month to clear a market. If that were true, our analysis with monthly observations and industry-wide measures of output and prices would be inadequate. Instead we would require higher frequency firm-level data. But, Bils and Klenow's (2004) detailed study of consumer price data tells us that this type of price adjustment is very rare, indeed. $^{22}$ Their source of information is unpublished BLS data from 1995-1997. Their data accounts for market prices of about 70 percent of total consumer spending. About 93 percent of the consumables in their study change price less frequently than once a month, on average, while roughly 76 percent of these consumables average more than two months between price changes. ${ }^{23}$ If high frequency equilibrium price adjustment occurs, it is extremely unusual.

We believe our results reinforce findings of Rotemberg (1982), Roberts et. al. (1994), Levy et. al. (1997), Gali and Gertler (1999), Sbordone (2002) and Ireland (2003). Each of these papers empirically tests a particular sticky price theory against a flexible price alternative and finds support for the sticky price model. An advantage of each of these papers is that they test a particular theory, and under the null hypothesis they are able to estimate structural parameters for the price adjustment process. Of course, if their model is misspecified inconsistent estimates are obtained. Misspecification may arise from the sticky 
price theory being false or if their approach requires joint estimation of other structural equations that are misspecified in some way. Inconsistent estimates would call into question conclusions regarding sticky price adjustment.

In contrast, our paper applies a smaller set of restrictions to the data to address the importance of sticky prices for economic fluctuations. Since we do not impose possibly incorrect over-identifying restrictions, the results in this paper are not conditioned on any particular theory. The advantage is that our findings are not premised on potentially inconsistent structural parameter estimates. Of course, if we knew the correct theoretical model, imposing those restrictions would yield efficiency gains. And, by not taking a stand on why prices are sticky, this paper is unable to determine if any particular sticky price theory can best explain the results. ${ }^{24}$

While this paper's results imply that sticky price adjustment plays an important role in output fluctuations, the overwhelming tendency for there to be little or no significant short-run co-movement between output and price is difficult to reconcile with existing sticky price models. Constructing and calibrating a sticky price model in which the innovations to price and output are uncorrelated and the short-run dynamic adjustments of these two variables are essentially independent remains a topic for future research. 


\section{Notes}

$1 \quad$ Mankiw and Romer (1991) includes seminal papers in this literature.

2 Hall, Walsh and Yates (2000) interviewed United Kingdom firms and obtained findings that are frequently similar to Blinder et. al. (1997).

3 Many theoretical models that were used initially to examine purely real phenomena have since been modified to allow for sticky prices. See Cooley and Hansen (1995) and Woodford (2003) for examples and additional references.

4 For the structure to be identified we also require that the shocks are uncorrelated and that the dynamics are invertible.

5 These data are from FRED, a data source provided by the Federal Reserve Bank of St. Louis.

6 Runkle (1987) was the first to use bootstrap methods with VAR models.

7 If innovations to a VAR system are uncorrelated, the ordering will not matter because every possible Cholesky decomposition obtains numerically identical results.

8 This point is argued intuitively here, and is formally derived in Section (3.3).

9 Cochrane (1998), for example, shows that money supply shocks may cause a hump-shaped response.

10 In both models with aggregate data the shock which immediately raises the price level is associated with a short-run increase in output. While that is not significant in either case, it comes close to being significant in the monthly Total IP model.

11 Measures of output exist for some service sector industries, but most of these data are of questionable quality. Griliches (1994,p.14) argues "we are not even close to a professional agreement on how to define and measure the output of banking, insurance, or the stock market (see Griliches, 1992). Similar difficulties arise in conceptualizing the output of health services, lawyers, and other consultants." More recent research on hard-to-measure markets can be found in Berndt and Hulten (2007).

12 This idea is related to Taylor (1999), which argues "it is likely that a full understanding of price and wage rigidities will eventually involve both imperfect information and staggered contracts of some form." Information imperfections could arise from the sticky information of Mankiw and Reis (2002), the rational attention of Sims (1998) or possibly some other mechanism.

13 More elaborate discussions of conditions that may lead to a vertical aggregate demand curve can be seen in the context of a more traditional setting by Fazzari, Ferri and Greenberg (1998) and in a Dynamic Stochastic General Equilibrium framework by Horvath (2009).

14 Output measures for Tobacco Products and Foods are actually taken from Industry Groupings because these data are combined into a single Market Grouping.

15 The CPI for House Furnishings is a reasonably compatible price series for Other Consumer Durables output, but not a perfect match.

16 Barsky, House and Kimball (2007) study what may happen to an economy when durable goods pricing behavior is different from non-durables pricing. While our paper does not directly address their model, our empirical findings provide no evidence to support that pricing assumption.

17 Boivin, Giannoni and Mihov (2009) estimate a model with aggregate shocks - monetary policy disturbances, for example - along with idiosyncratic market-specific shocks using factor augmented VARs.

18 Miron (1996) discusses a variety of situations in which not seasonally adjusted data may be preferable.

19 In each case, the impulse responses from seasonally adjusted and not seasonally adjusted data tell basically the same story. The only essential difference is that the not seasonally adjusted data often obtain very cyclical impulse responses.

20 This normalization has absolutely no effect on impulse responses or variance decompositions. 
21 These responses are not statistically significant, however. This dynamic restrictions model has relatively large standard errors for the variance decomposition and relatively wide confidence intervals on the impulse responses. These obtain because the denominator of equation (13) is imprecisely estimated, and so it varies over a wide range of positive and negative values in the bootstrap simulations.

22 Blinder's surveys also allow one to conclude that prices change infrequently. We focus on Bils and Klenow's evidence as it is more closely related to the data used here.

23 These numbers are obtained from the table in the Appendix of Bils and Klenow (2004).

24 Theories in which a small amount of price stickiness at the micro level causes a large amount of stickiness at the macro level do not explain our main results which are robust to various levels of aggregation. Blanchard (1987) and Kehoe and Midrigan (2010) are interesting dissimilar examples of models that generate substantial aggregate price stickiness from a smaller amount at the micro level. 


\section{References}

Barsky, Robert, Christopher L. House, Miles Kimball (2007) "Sticky Price Models and Durable Goods," American Economic Review, 97: 984-998

Berndt, Ernst R. and Charles M. Hulten, Editors (2007) Hard-to-Measure Goods and Services: Essays in Honor of Zvi Griliches, National Bureau of Economic Research, University of Chicago Press.

Bils, Mark Bils and Peter J. Klenow (2004) "Some Evidence on the Importance of Sticky Prices." Journal of Political Economy, vol. 112, no. 5, 947-985.

Blanchard, Olivier J. (1987) “Aggregate and Individual Price Adjustment” Brookings Papers on Economic Activity, Vol. 1987, No. 1, 57-122.

Blinder, Alan S. (1994) "On Sticky Prices: Academic Theories Meet the Real World," in Monetary Policy, ed. N.G. Mankiw, 117-50.

Blinder, Alan S., Elie R. D. Canetti, David E. Lebow, and Jeremy B. Rudd (1997) Asking About Prices: A New Approach to Understanding Price Stickiness, Russell Sage Foundation, New York.

Boivin, Jean, Marc Giannoni and Ilian Mihov (2009) "Sticky Prices and Monetary Policy: Evidence from Disaggregated U.S. Data" American Economic Review 99, 350-384.

Caplin, Andrew S. and Daniel F. Spulber (1987) "Menu Costs and the Neutrality of Money," Quarterly Journal of Economics 102(4), November 1987, 703-25.

Carlton, Dennis W. (1986) "The Rigidity of Prices," American Economic Review, 76:637-658.

Cecchetti, Steven G. (1986) "The Frequency of Price Adjustment: A Study of the Newsstand Prices of Magazines," Journal of Econometrics, 31:255-274.

Cochrane, John H. (1998) "What Do VARs Mean?: Measuring the Output Effects of Money," Journal of Monetary Economics 41, 277-300.

Cooley, Thomas and Gary Hansen (1995) "Money and the Business Cycle," in Frontiers of Business Cycle Research, ed. T. Cooley.

Farmer, Roger E. A. (1992) "Nominal Price Stickiness as a Rational Expectations Equilibrium," Journal of Economic Dynamics and Control, 16:317-337.

Farmer, Roger E. A. (2000) “Two New-Keynesian Theories of Sticky Prices," Macroeconomic Dynamics 4, 74-107.

Fazzari, Steven M., Piero Ferri and Edward Greenberg (1998) "Aggregate Demand and Firm Behavior: A New Perspective on Keynesian Microfoundations," Journal of Post Keynesian Economics 20: 527-558.

Gali, Jordi and Mark Gertler (1999) "Inflation Dynamics: A Structural Econometric Analysis," Journal of Monetary Economics 44: 195-222.

Griliches, Zvi (1992) "Introduction," Output Measurement in the Service Sectors, ed. Z Griliches, NBER Studies in Income and Wealth, Vol 56. Chicago: University of Chicago Press, 1-22. 
Griliches, Zvi (1994) "Productivity, R\&D and the Data Constraint," American Economic Review 84, 1-23.

Hall, Simon, Mark Walsh and Anthony Yates (2000) “Are U.K. Companies' Prices Sticky?,” Oxford Economic Papers 52, 425-446.

Horvath, Michal (2009) "The Effects of Government Spending Shocks on Consumption under Optimal Stabilization,” European Economic Review 53:7, 815-829

Ireland, Peter (2003) “Endogenous Money or Sticky Prices?” Journal of Monetary Economics, 50, Issue 8, November, 1623-1648.

Kashyap, Anil K. (1995) "Sticky Prices: New Evidence from Retail Catalogs," Quarterly Journal of Economics, 110:245-74.

Kehoe, Patrick J. and Virgiliu Midrigan (2010) "Prices are Sticky After All," National Bureau of Economic Research, Working Paper 16364.

Levy, Daniel, Mark Bergen, Shantanu Dutta, and Robert Venable (1997) "The Magnitude of Menu Costs: Direct Evidence from Large U.S. Supermarket Chains," Quarterly Journal of Economics 112: 791-825.

Mankiw, N. Gregory and Ricardo Reis (2002) "Sticky Information Versus Sticky Prices: A Proposal to Replace the New-Keynesian Phillips Curve," Quarterly Journal of Economics 1295-1328.

Mankiw, N. Gregory and David Romer (1991) New Keynesian Economics, MIT Press, Cambridge.

Mills, Frederick C. (1927) The Behavior of Prices, National Bureau of Economic Research, New York.

Miron, Jeffrey A. (1996) The Economics of Seasonal Cycles, MIT Press, Cambridge.

$\mathrm{Ng}$, Serena (2003) "Can Sticky Prices Account for the Variations and Persistence in Real Exchange Rates?," Journal of International Money and Finance, vol. 22(1), pages 65-85.

Ohanian, Lee E., Alan C. Stockman and Lutz Kilian (1995) "The Effects of Real and Monetary Shocks in a Business Cycle Model with Some Sticky Prices," Journal of Money, Credit and Banking 27:1210-1234.

Roberts, John M., David J. Stockton and Charles S. Struckmeyer (1994) "Evidence on the Flexibility of Prices," Review of Economics and Statistics 76: 142-150.

Rotemberg, Julio J. (1982) "Sticky Prices in the United States," Journal of Political Economy, Vol. 90, No. 6. (Dec.), pp. 1187-1211.

Runkle, David E. (1987) "Vector Autoregressions and Reality," Journal of Business and Economic Statistics, 5:437-54.

Sbordone, Argia M. (2002) "Prices and Unit Labor Costs: A New Test of Price Stickiness," Journal of Monetary Economics 49 (March): 265-92.

Sims, Christopher A. (1998) "Stickiness," Carnegie-Rochester Conference Series on Public Policy 49:317-356.

Stigler George J. and James K. Kindahl (1970) The Behavior of Industrial Prices, National Bureau of 
Economic Research, New York.

Taylor, John B. (1999) "Staggered Price and Wage Setting in Macroeconomics," Chapter 15 in Handbook of Macroeconomics, J. B. Taylor \& M. Woodford (ed.), 1009-1050.

Willis, Jonathan L. (2006) “Magazine Prices Revisited," Journal of Applied Econometrics, Volume 21, Issue 3, 337 - 344 .

Woodford, M. (2003) Interest and Prices: Foundations of a Theory of Monetary Policy, Princeton University Press.

Wynne, Mark (1995) "Sticky Prices: What is the Evidence?," Federal Reserve Bank of Dallas, Economic Review, First Quarter, 1-12. 
Table 1: Chained-Weighed Gross Domestic Product Data Variance Decomposition

\begin{tabular}{|c|c|c|c|}
\hline Variable & $\begin{array}{l}\text { Quarter(s) } \\
\text { Ahead }\end{array}$ & $\begin{array}{l}\text { Innovation to the } \\
\text { Price Level }\end{array}$ & $\begin{array}{l}\text { Shock with No Effect } \\
\text { on Price for } 1 \text { Quarter }\end{array}$ \\
\hline \multirow[t]{15}{*}{ Output } & 1 & 0 & 100 \\
\hline & \multirow[t]{2}{*}{2} & $\begin{array}{c}(1) \\
0\end{array}$ & $\begin{array}{l}\text { (1) } \\
100\end{array}$ \\
\hline & & (1) & (1) \\
\hline & \multirow[t]{2}{*}{4} & 0 & 100 \\
\hline & & (1) & (1) \\
\hline & \multirow[t]{2}{*}{8} & 2 & 98 \\
\hline & & (4) & (4) \\
\hline & \multirow[t]{2}{*}{12} & 4 & 96 \\
\hline & & (6) & (6) \\
\hline & \multirow[t]{2}{*}{24} & 8 & 92 \\
\hline & & (10) & (10) \\
\hline & \multirow[t]{2}{*}{40} & 8 & 92 \\
\hline & & (10) & (10) \\
\hline & \multirow[t]{2}{*}{100} & 5 & 95 \\
\hline & & (11) & (11) \\
\hline \multirow[t]{15}{*}{ Price } & 1 & 100 & 0 \\
\hline & \multirow[t]{2}{*}{2} & 100 & 0 \\
\hline & & $(0)$ & (0) \\
\hline & \multirow[t]{2}{*}{4} & 97 & 3 \\
\hline & & (2) & (2) \\
\hline & \multirow[t]{2}{*}{8} & 94 & 6 \\
\hline & & (4) & (4) \\
\hline & \multirow[t]{2}{*}{12} & 92 & 8 \\
\hline & & (6) & (6) \\
\hline & \multirow[t]{2}{*}{24} & 85 & 15 \\
\hline & & (11) & (11) \\
\hline & \multirow[t]{2}{*}{40} & 75 & 25 \\
\hline & & (14) & (14) \\
\hline & \multirow[t]{2}{*}{100} & 50 & 50 \\
\hline & & (16) & (16) \\
\hline
\end{tabular}

Standard errors are in parentheses. Some standard errors round to zero. 
Table 2: Total Industrial Production and Consumer Market Groups, Seasonally Adjusted Data, Variance Explained by Shocks that Have No Effect on Price for 1 Month

\begin{tabular}{|c|c|c|c|c|c|c|c|c|c|}
\hline Variable & $\begin{array}{c}\text { Month(s) } \\
\text { Ahead }\end{array}$ & Total IP & Trucks & Autos & $\begin{array}{c}\text { Other } \\
\text { Durables }\end{array}$ & Clothing & Energy & Food & Tobacco \\
\hline \multirow[t]{20}{*}{ Output } & \multirow[t]{2}{*}{1} & 100 & 100 & 100 & 100 & 100 & 100 & 99 & 100 \\
\hline & & $(0)$ & (1) & $(0)$ & $(0)$ & $(0)$ & $(0)$ & (1) & (1) \\
\hline & \multirow[t]{2}{*}{2} & 100 & 100 & 100 & 100 & 100 & 100 & 99 & 100 \\
\hline & & (1) & (1) & (1) & (1) & $(0)$ & (1) & (1) & (1) \\
\hline & \multirow[t]{2}{*}{3} & 99 & 100 & 100 & 99 & 100 & 100 & 99 & 99 \\
\hline & & (1) & (1) & (1) & (1) & (0) & (1) & (2) & (2) \\
\hline & \multirow[t]{2}{*}{6} & 99 & 99 & 100 & 93 & 100 & 97 & 99 & 95 \\
\hline & & (1) & (2) & (1) & (4) & (1) & (2) & (2) & (5) \\
\hline & \multirow[t]{2}{*}{9} & 99 & 99 & 99 & 84 & 100 & 95 & 99 & 87 \\
\hline & & (2) & (3) & (2) & (6) & (1) & (3) & (2) & (8) \\
\hline & \multirow[t]{2}{*}{12} & 99 & 98 & 99 & 75 & 99 & 94 & 99 & 84 \\
\hline & & (1) & (4) & (3) & (8) & (3) & (4) & (1) & (1) \\
\hline & \multirow[t]{2}{*}{24} & 96 & 95 & 99 & 52 & 98 & 91 & 99 & 71 \\
\hline & & (4) & (7) & (3) & (12) & (4) & (6) & (1) & (14) \\
\hline & \multirow[t]{2}{*}{36} & 90 & 90 & 99 & 43 & 96 & 90 & 99 & 64 \\
\hline & & (8) & (9) & (4) & (13) & (5) & (6) & (2) & (15) \\
\hline & \multirow[t]{2}{*}{72} & 82 & 77 & 99 & 39 & 93 & 90 & 98 & 54 \\
\hline & & (12) & (9) & (4) & (14) & (7) & (7) & (5) & (15) \\
\hline & \multirow[t]{2}{*}{300} & 85 & 74 & 98 & 37 & 73 & 93 & 89 & 38 \\
\hline & & (12) & (10) & (4) & (13) & (18) & (9) & (10) & (18) \\
\hline \multirow[t]{19}{*}{ Price } & 1 & 0 & 0 & 0 & 0 & 0 & 0 & 0 & 0 \\
\hline & \multirow[t]{2}{*}{2} & 0 & 1 & 0 & 0 & 0 & 2 & 0 & 0 \\
\hline & & (0) & (1) & (0) & (0) & (0) & (1) & (0) & (1) \\
\hline & \multirow[t]{2}{*}{3} & 0 & 1 & 0 & 0 & 0 & 3 & 0 & 1 \\
\hline & & (0) & (1) & (0) & (0) & (0) & (1) & (0) & (1) \\
\hline & \multirow[t]{2}{*}{6} & 2 & 2 & 1 & 0 & 0 & 2 & 0 & 1 \\
\hline & & (1) & (2) & (1) & (1) & (1) & (2) & (0) & (2) \\
\hline & \multirow[t]{2}{*}{9} & 3 & 3 & 1 & 1 & 1 & 3 & 0 & 1 \\
\hline & & (2) & (3) & (2) & (1) & (1) & (2) & (1) & (2) \\
\hline & \multirow[t]{2}{*}{12} & 5 & 6 & 2 & 2 & 2 & 3 & 0 & 1 \\
\hline & & (3) & (4) & (3) & (2) & (2) & (3) & (1) & (3) \\
\hline & \multirow[t]{2}{*}{24} & 10 & 19 & 1 & 3 & 4 & 6 & 2 & 1 \\
\hline & & (6) & (10) & (4) & (4) & (4) & (6) & (4) & (5) \\
\hline & \multirow[t]{2}{*}{36} & 12 & 29 & 1 & 3 & 6 & 10 & 5 & 0 \\
\hline & & (7) & (13) & (5) & (6) & (5) & (10) & (7) & (8) \\
\hline & \multirow[t]{2}{*}{72} & 22 & 46 & 5 & 4 & 13 & 25 & 15 & 1 \\
\hline & & (12) & (18) & (9) & (10) & (10) & (17) & (13) & (13) \\
\hline & \multirow[t]{2}{*}{300} & 67 & 57 & 10 & 3 & 79 & 68 & 36 & 3 \\
\hline & & (14) & (21) & (13) & (14) & (20) & (19) & (21) & (18) \\
\hline
\end{tabular}

Standard errors are in parentheses. Some standard errors round to zero. 
Table 3: Non-Food Industries that Primarily Serve Consumers, Seasonally Adjusted Data, Variance Explained by Shocks that Have No Effect on Price for 1 Month

\begin{tabular}{|c|c|c|c|}
\hline Variable & $\begin{array}{c}\text { Month(s) } \\
\text { Ahead }\end{array}$ & $\begin{array}{c}\text { Automotive } \\
\text { Gas }\end{array}$ & Furniture \\
\hline \multirow[t]{19}{*}{ Output } & 1 & $\begin{array}{c}100 \\
(1)\end{array}$ & $\begin{array}{c}100 \\
(0)\end{array}$ \\
\hline & \multirow[t]{2}{*}{2} & 100 & 99 \\
\hline & & (1) & (1) \\
\hline & \multirow[t]{2}{*}{3} & 100 & 99 \\
\hline & & (1) & (1) \\
\hline & \multirow[t]{2}{*}{6} & 99 & 98 \\
\hline & & (2) & (2) \\
\hline & \multirow[t]{2}{*}{9} & 99 & 97 \\
\hline & & (2) & (3) \\
\hline & \multirow[t]{2}{*}{12} & 99 & 97 \\
\hline & & (2) & (3) \\
\hline & \multirow[t]{2}{*}{24} & 100 & 97 \\
\hline & & (2) & (3) \\
\hline & \multirow[t]{2}{*}{36} & 100 & 97 \\
\hline & & (3) & (3) \\
\hline & \multirow[t]{2}{*}{72} & 100 & 97 \\
\hline & & (6) & (3) \\
\hline & \multirow[t]{2}{*}{300} & 100 & 94 \\
\hline & & (8) & (5) \\
\hline \multirow[t]{19}{*}{ Price } & 1 & 0 & 0 \\
\hline & \multirow[t]{2}{*}{2} & 0 & 0 \\
\hline & & $(0)$ & $(0)$ \\
\hline & \multirow[t]{2}{*}{3} & 0 & 0 \\
\hline & & $(0)$ & $(0)$ \\
\hline & \multirow[t]{2}{*}{6} & 0 & 1 \\
\hline & & (1) & (1) \\
\hline & \multirow[t]{2}{*}{9} & 1 & 1 \\
\hline & & (1) & (2) \\
\hline & \multirow[t]{2}{*}{12} & 2 & 2 \\
\hline & & (3) & (2) \\
\hline & \multirow[t]{2}{*}{24} & 13 & 2 \\
\hline & & (9) & (3) \\
\hline & \multirow[t]{2}{*}{36} & 29 & 2 \\
\hline & & (13) & (4) \\
\hline & \multirow[t]{2}{*}{72} & 62 & 1 \\
\hline & & (17) & (6) \\
\hline & \multirow[t]{2}{*}{300} & 88 & 1 \\
\hline & & (19) & (9) \\
\hline
\end{tabular}

Standard errors are in parentheses. Some standard errors round to zero. 
Table 4:

Food Industries, Seasonally Adjusted Data

Variance Explained by Shocks that Have No Effect on Price for 1 Month

\begin{tabular}{|c|c|c|c|c|c|c|c|c|c|}
\hline Variable & $\begin{array}{c}\text { Month(s) } \\
\text { Ahead }\end{array}$ & Beef & Pork & Poultry & Butter & Cheese & $\begin{array}{c}\text { Dairy } \\
\text { Products } \\
\end{array}$ & Beer & $\begin{array}{c}\text { Soft } \\
\text { Drinks }\end{array}$ \\
\hline \multirow[t]{20}{*}{ Output } & \multirow[t]{2}{*}{1} & 83 & 92 & 100 & 98 & 100 & 100 & 99 & 100 \\
\hline & & (4) & (2) & (1) & (1) & (1) & (1) & (1) & (1) \\
\hline & \multirow[t]{2}{*}{2} & 79 & 91 & 99 & 97 & 100 & 99 & 100 & 99 \\
\hline & & (5) & (3) & (3) & (2) & (1) & (1) & (1) & (1) \\
\hline & \multirow[t]{2}{*}{3} & 77 & 92 & 99 & 97 & 100 & 99 & 99 & 98 \\
\hline & & (6) & (3) & (3) & (2) & (1) & (2) & (1) & (2) \\
\hline & \multirow[t]{2}{*}{6} & 80 & 94 & 99 & 96 & 100 & 97 & 98 & 96 \\
\hline & & (6) & (3) & (3) & (3) & (1) & (4) & (2) & (3) \\
\hline & \multirow[t]{2}{*}{9} & 82 & 95 & 99 & 95 & 99 & 94 & 98 & 96 \\
\hline & & (6) & (3) & (5) & (3) & (2) & (5) & (3) & (4) \\
\hline & \multirow[t]{2}{*}{12} & 83 & 94 & 98 & 95 & 99 & 90 & 96 & 96 \\
\hline & & (6) & (4) & (7) & (4) & (3) & (7) & (4) & (4) \\
\hline & \multirow[t]{2}{*}{24} & 86 & 66 & 90 & 94 & 95 & 74 & 92 & 97 \\
\hline & & (6) & (12) & (15) & (6) & (8) & (11) & (7) & (3) \\
\hline & \multirow[t]{2}{*}{36} & 88 & 60 & 79 & 92 & 90 & 60 & 91 & 98 \\
\hline & & (5) & (12) & (18) & (8) & (11) & (13) & (8) & (3) \\
\hline & \multirow[t]{2}{*}{72} & 89 & 52 & 55 & 88 & 79 & 40 & 90 & 98 \\
\hline & & (6) & (13) & (21) & (12) & (17) & (14) & (8) & (4) \\
\hline & \multirow[t]{2}{*}{300} & 85 & 37 & 29 & 81 & 65 & 28 & 91 & 97 \\
\hline & & (11) & (15) & (25) & (18) & (22) & (16) & (9) & (7) \\
\hline \multirow[t]{19}{*}{ Price } & 1 & 0 & 0 & 0 & 0 & 0 & 0 & 0 & 0 \\
\hline & \multirow[t]{2}{*}{2} & 1 & 3 & 1 & 1 & 0 & 0 & 0 & 0 \\
\hline & & (1) & (2) & (2) & (1) & (0) & (0) & (0) & (0) \\
\hline & \multirow[t]{2}{*}{3} & 1 & 8 & 1 & 1 & 1 & 0 & 1 & 0 \\
\hline & & (1) & (3) & (2) & (1) & (1) & (0) & (1) & (1) \\
\hline & \multirow[t]{2}{*}{6} & 1 & 15 & 5 & 1 & 1 & 0 & 1 & 2 \\
\hline & & (1) & (6) & (5) & (1) & (1) & (1) & (2) & (2) \\
\hline & \multirow[t]{2}{*}{9} & 1 & 19 & 6 & 1 & 2 & 0 & 2 & 3 \\
\hline & & (1) & (8) & (5) & (2) & (2) & (1) & (3) & (3) \\
\hline & \multirow[t]{2}{*}{12} & 1 & 21 & 6 & 2 & 3 & 0 & 3 & 6 \\
\hline & & (2) & (9) & (6) & (3) & (3) & (2) & (4) & (5) \\
\hline & \multirow[t]{2}{*}{24} & 5 & 24 & 4 & 3 & 7 & 0 & 5 & 17 \\
\hline & & (7) & (11) & (7) & (6) & (8) & (4) & (7) & (10) \\
\hline & \multirow[t]{2}{*}{36} & 12 & 24 & 3 & 4 & 11 & 0 & 6 & 29 \\
\hline & & (11) & (10) & (10) & (8) & (11) & (5) & (11) & (14) \\
\hline & \multirow[t]{2}{*}{72} & 30 & 21 & 2 & 6 & 21 & 1 & 11 & 51 \\
\hline & & (17) & (10) & (14) & (11) & (17) & (7) & (17) & (19) \\
\hline & \multirow[t]{2}{*}{300} & 54 & 20 & 2 & 9 & 36 & 1 & 21 & 72 \\
\hline & & (21) & (13) & (17) & (14) & (22) & (8) & (24) & (22) \\
\hline
\end{tabular}

Standard errors are in parentheses. Some standard errors round to zero. 
Table 5: Total Industrial Production and Consumer Market Groups, Not Seasonally Adjusted Data Variance Explained by Shocks that Have No Effect on Price for 1 Month

\begin{tabular}{|c|c|c|c|c|c|c|c|c|c|}
\hline Variable & $\begin{array}{c}\text { Month(s) } \\
\text { Ahead }\end{array}$ & Total IP & Trucks & Autos & $\begin{array}{c}\text { Other } \\
\text { Durables }\end{array}$ & Clothing & Energy & Food & Tobacco \\
\hline \multirow[t]{20}{*}{ Output } & \multirow[t]{2}{*}{1} & 100 & 100 & 100 & 100 & 100 & 100 & 100 & 99 \\
\hline & & (0) & (1) & (0) & (0) & (0) & (1) & (1) & (1) \\
\hline & \multirow[t]{2}{*}{2} & 100 & 99 & 100 & 100 & 100 & 100 & 100 & 99 \\
\hline & & (0) & (2) & $(1)$ & (1) & (0) & $(1)$ & $(1)$ & (1) \\
\hline & \multirow[t]{2}{*}{3} & 100 & 99 & 100 & 99 & 100 & 100 & 100 & 99 \\
\hline & & $(1)$ & (2) & $(1)$ & (2) & (0) & $(1)$ & $(1)$ & (2) \\
\hline & \multirow[t]{2}{*}{6} & 99 & 98 & 99 & 89 & 100 & 96 & 98 & 94 \\
\hline & & (1) & (3) & (1) & (5) & (1) & (3) & (3) & (4) \\
\hline & \multirow[t]{2}{*}{9} & 100 & 91 & 99 & 75 & 100 & 96 & 95 & 87 \\
\hline & & (1) & (7) & (2) & (8) & (1) & (3) & (5) & (7) \\
\hline & \multirow[t]{2}{*}{12} & 99 & 86 & 99 & 63 & 100 & 95 & 91 & 85 \\
\hline & & (1) & (9) & (3) & (10) & $(2)$ & (3) & (6) & (8) \\
\hline & \multirow[t]{2}{*}{24} & 91 & 86 & 98 & 56 & 99 & 83 & 71 & 76 \\
\hline & & (7) & (9) & (4) & (13) & (3) & (6) & (11) & (11) \\
\hline & \multirow[t]{2}{*}{36} & 88 & 82 & 97 & 55 & 99 & 78 & 67 & 71 \\
\hline & & (9) & (9) & (4) & (15) & (3) & (8) & (12) & (13) \\
\hline & \multirow[t]{2}{*}{72} & 85 & 74 & 97 & 52 & 99 & 64 & 67 & 65 \\
\hline & & (13) & (10) & (5) & (15) & (5) & (12) & (12) & (13) \\
\hline & \multirow[t]{2}{*}{300} & 85 & 61 & 97 & 56 & 92 & 55 & 72 & 58 \\
\hline & & (16) & (11) & (5) & (15) & (14) & (16) & (11) & (13) \\
\hline \multirow[t]{19}{*}{ Price } & 1 & 0 & 0 & 0 & 0 & 0 & 0 & 0 & 0 \\
\hline & \multirow[t]{2}{*}{2} & 0 & 1 & 0 & 0 & 0 & 2 & 0 & 0 \\
\hline & & (0) & (1) & (0) & (0) & (0) & (1) & (0) & (0) \\
\hline & \multirow[t]{2}{*}{3} & 0 & 2 & 0 & 0 & 0 & 2 & 1 & 0 \\
\hline & & (0) & (2) & (1) & (0) & (0) & (1) & (1) & (0) \\
\hline & \multirow[t]{2}{*}{6} & 2 & 3 & 1 & 0 & 0 & 1 & 0 & 0 \\
\hline & & (2) & (3) & (1) & (1) & (1) & (1) & (1) & (1) \\
\hline & \multirow[t]{2}{*}{9} & 5 & 5 & 1 & 0 & 1 & 2 & 0 & 0 \\
\hline & & (3) & (5) & (2) & (1) & (1) & (2) & (1) & (1) \\
\hline & \multirow[t]{2}{*}{12} & 7 & 10 & 1 & 0 & 1 & 1 & 0 & 0 \\
\hline & & (4) & (7) & (3) & (2) & (2) & (3) & (2) & (2) \\
\hline & \multirow[t]{2}{*}{24} & 14 & 30 & 1 & 1 & 3 & 1 & 4 & 0 \\
\hline & & (8) & (14) & (5) & (4) & (4) & (3) & (6) & (3) \\
\hline & \multirow[t]{2}{*}{36} & 22 & 36 & 2 & 7 & 4 & 1 & 7 & 1 \\
\hline & & (12) & (16) & (6) & (10) & (6) & (5) & (10) & (6) \\
\hline & \multirow[t]{2}{*}{72} & 37 & 39 & 12 & 37 & 8 & 4 & 13 & 6 \\
\hline & & (17) & (18) & (11) & (20) & (9) & (11) & (13) & (13) \\
\hline & \multirow[t]{2}{*}{300} & 68 & 41 & 13 & 35 & 69 & 28 & 33 & 17 \\
\hline & & (17) & (20) & (12) & (24) & (22) & (14) & (16) & (21) \\
\hline
\end{tabular}

Standard errors are in parentheses. Some standard errors round to zero. 
Table 6: Non-Food Industries that Primarily Serve Consumers, Not Seasonally Adjusted Data Variance Explained by Shocks that Have No Effect on Price for 1 Month

\begin{tabular}{|c|c|c|c|}
\hline Variable & $\begin{array}{l}\text { Month(s) } \\
\text { Ahead }\end{array}$ & Furniture & $\begin{array}{c}\text { Automotive } \\
\text { Gas }\end{array}$ \\
\hline \multirow[t]{12}{*}{ Output } & 1 & $\begin{array}{l}100 \\
(0)\end{array}$ & $\begin{array}{l}100 \\
(1)\end{array}$ \\
\hline & 2 & $\begin{array}{l}99 \\
(1)\end{array}$ & $\begin{array}{l}99 \\
(1)\end{array}$ \\
\hline & 3 & $\begin{array}{l}98 \\
(2)\end{array}$ & $\begin{array}{l}99 \\
(1)\end{array}$ \\
\hline & 6 & 94 & 98 \\
\hline & & (4) & (2) \\
\hline & 9 & $\begin{array}{l}89 \\
(6)\end{array}$ & $\begin{array}{l}97 \\
(3)\end{array}$ \\
\hline & 12 & $\begin{array}{l}85 \\
(8)\end{array}$ & $\begin{array}{l}98 \\
(3)\end{array}$ \\
\hline & 24 & 85 & 98 \\
\hline & & (10) & (4) \\
\hline & 36 & $\begin{array}{c}86 \\
(11)\end{array}$ & $\begin{array}{l}99 \\
(4)\end{array}$ \\
\hline & 72 & $\begin{array}{c}79 \\
(11)\end{array}$ & $\begin{array}{l}99 \\
(6)\end{array}$ \\
\hline & 300 & $\begin{array}{c}60 \\
(13)\end{array}$ & $\begin{array}{l}99 \\
(9)\end{array}$ \\
\hline \multirow[t]{13}{*}{ Price } & 1 & 0 & 0 \\
\hline & 2 & 0 & 0 \\
\hline & & (0) & (0) \\
\hline & 3 & $\begin{array}{c}0 \\
(1)\end{array}$ & $\begin{array}{c}0 \\
(0)\end{array}$ \\
\hline & 6 & $\begin{array}{c}1 \\
(1)\end{array}$ & $\begin{array}{c}0 \\
(1)\end{array}$ \\
\hline & 9 & 1 & 3 \\
\hline & & $(2)$ & (3) \\
\hline & 12 & 1 & 4 \\
\hline & & (2) & (4) \\
\hline & 24 & $\begin{array}{c}3 \\
(5)\end{array}$ & $\begin{array}{c}18 \\
(10)\end{array}$ \\
\hline & 36 & $\begin{array}{c}9 \\
(10)\end{array}$ & $\begin{array}{c}33 \\
(14)\end{array}$ \\
\hline & 72 & $\begin{array}{c}24 \\
(18)\end{array}$ & $\begin{array}{c}62 \\
(17)\end{array}$ \\
\hline & 300 & $\begin{array}{c}20 \\
(20)\end{array}$ & $\begin{array}{c}84 \\
(19)\end{array}$ \\
\hline
\end{tabular}

Standard errors are in parentheses. Some standard errors round to zero. 
Table 7:

Food Industries, Not Seasonally Adjusted Data

Variance Explained by Shocks that Have No Effect on Price for 1 Month

\begin{tabular}{|c|c|c|c|c|c|c|c|c|c|}
\hline Variable & $\begin{array}{l}\text { Month(s) } \\
\text { Ahead }\end{array}$ & Beef & Pork & Poultry & Butter & Cheese & $\begin{array}{c}\text { Dairy } \\
\text { Products }\end{array}$ & Beer & $\begin{array}{c}\text { Soft } \\
\text { drinks }\end{array}$ \\
\hline \multirow{20}{*}{ Output } & \multirow{2}{*}{1} & 86 & 93 & 96 & 100 & 100 & 100 & 100 & 100 \\
\hline & & (5) & (3) & (2) & (1) & (1) & (1) & $(1)$ & (1) \\
\hline & \multirow[t]{2}{*}{2} & 83 & 93 & 97 & 100 & 100 & 100 & 100 & 100 \\
\hline & & (5) & (3) & (2) & (1) & (1) & (1) & $(1)$ & $(1)$ \\
\hline & \multirow[t]{2}{*}{3} & 80 & 94 & 97 & 100 & 100 & 99 & 100 & 100 \\
\hline & & (6) & (3) & (2) & (1) & (1) & (1) & $(1)$ & (1) \\
\hline & \multirow[t]{2}{*}{6} & 80 & 95 & 96 & 99 & 99 & 99 & 99 & 100 \\
\hline & & (7) & (3) & (2) & (3) & (2) & $(2)$ & (2) & $(2)$ \\
\hline & \multirow[t]{2}{*}{9} & 79 & 96 & 90 & 98 & 97 & 99 & 98 & 98 \\
\hline & & (7) & (2) & (6) & (3) & (4) & (2) & (3) & (3) \\
\hline & \multirow[t]{2}{*}{12} & 77 & 96 & 83 & 96 & 95 & 99 & 97 & 96 \\
\hline & & (8) & (3) & (8) & (5) & (5) & (3) & (4) & (5) \\
\hline & \multirow[t]{2}{*}{24} & 61 & 72 & 64 & 93 & 87 & 98 & 93 & 95 \\
\hline & & (10) & (10) & (13) & (8) & (11) & (4) & (7) & (8) \\
\hline & \multirow[t]{2}{*}{36} & 59 & 67 & 56 & 93 & 81 & 98 & 93 & 94 \\
\hline & & (11) & (11) & (14) & (8) & (14) & (4) & (7) & (10) \\
\hline & \multirow[t]{2}{*}{72} & 60 & 63 & 38 & 92 & 73 & 97 & 94 & 94 \\
\hline & & (11) & (10) & (15) & (8) & (19) & (6) & (7) & (10) \\
\hline & \multirow[t]{2}{*}{300} & 64 & 48 & 22 & 92 & 65 & 87 & 95 & 94 \\
\hline & & (10) & (11) & (16) & (9) & (24) & (9) & (9) & (11) \\
\hline \multirow[t]{19}{*}{ Price } & 1 & 0 & 0 & 0 & 0 & 0 & 0 & 0 & 0 \\
\hline & \multirow[t]{2}{*}{2} & 2 & 7 & 2 & 1 & 0 & 0 & 0 & 0 \\
\hline & & (1) & (2) & (1) & (1) & (0) & (0) & (0) & (0) \\
\hline & \multirow[t]{2}{*}{3} & 2 & 12 & 3 & 2 & 0 & 0 & 1 & 0 \\
\hline & & (1) & (3) & (2) & (1) & (0) & (1) & (1) & (1) \\
\hline & \multirow[t]{2}{*}{6} & 1 & 17 & 6 & 11 & 0 & 6 & 1 & 1 \\
\hline & & (2) & (6) & (4) & (5) & (1) & (4) & (2) & (1) \\
\hline & \multirow[t]{2}{*}{9} & 1 & 20 & 10 & 14 & 0 & 13 & 2 & 1 \\
\hline & & (2) & (7) & (6) & (6) & (1) & (7) & (3) & (2) \\
\hline & \multirow[t]{2}{*}{12} & 1 & 19 & 12 & 15 & 0 & 16 & 2 & 2 \\
\hline & & (2) & (8) & (7) & (8) & (2) & (8) & (4) & (4) \\
\hline & \multirow[t]{2}{*}{24} & 2 & 21 & 15 & 20 & 5 & 17 & 5 & 14 \\
\hline & & (4) & (9) & (8) & (11) & (8) & (10) & (8) & (10) \\
\hline & \multirow[t]{2}{*}{36} & 7 & 21 & 15 & 20 & 12 & 15 & 6 & 38 \\
\hline & & (8) & (9) & (8) & (13) & (14) & (10) & (10) & (15) \\
\hline & \multirow[t]{2}{*}{72} & 21 & 22 & 14 & 31 & 27 & 12 & 5 & 66 \\
\hline & & (11) & (8) & (9) & (18) & (20) & (10) & (13) & (15) \\
\hline & \multirow[t]{2}{*}{300} & 45 & 16 & 12 & 43 & 43 & 15 & 2 & 78 \\
\hline & & (14) & (9) & (12) & (22) & (25) & (15) & (19) & (16) \\
\hline
\end{tabular}

Standard errors are in parentheses. Some standard errors round to zero. 
Table 8: IP, CPI and Fed Funds Rate, Seasonally Adjusted Data Variance Decomposition

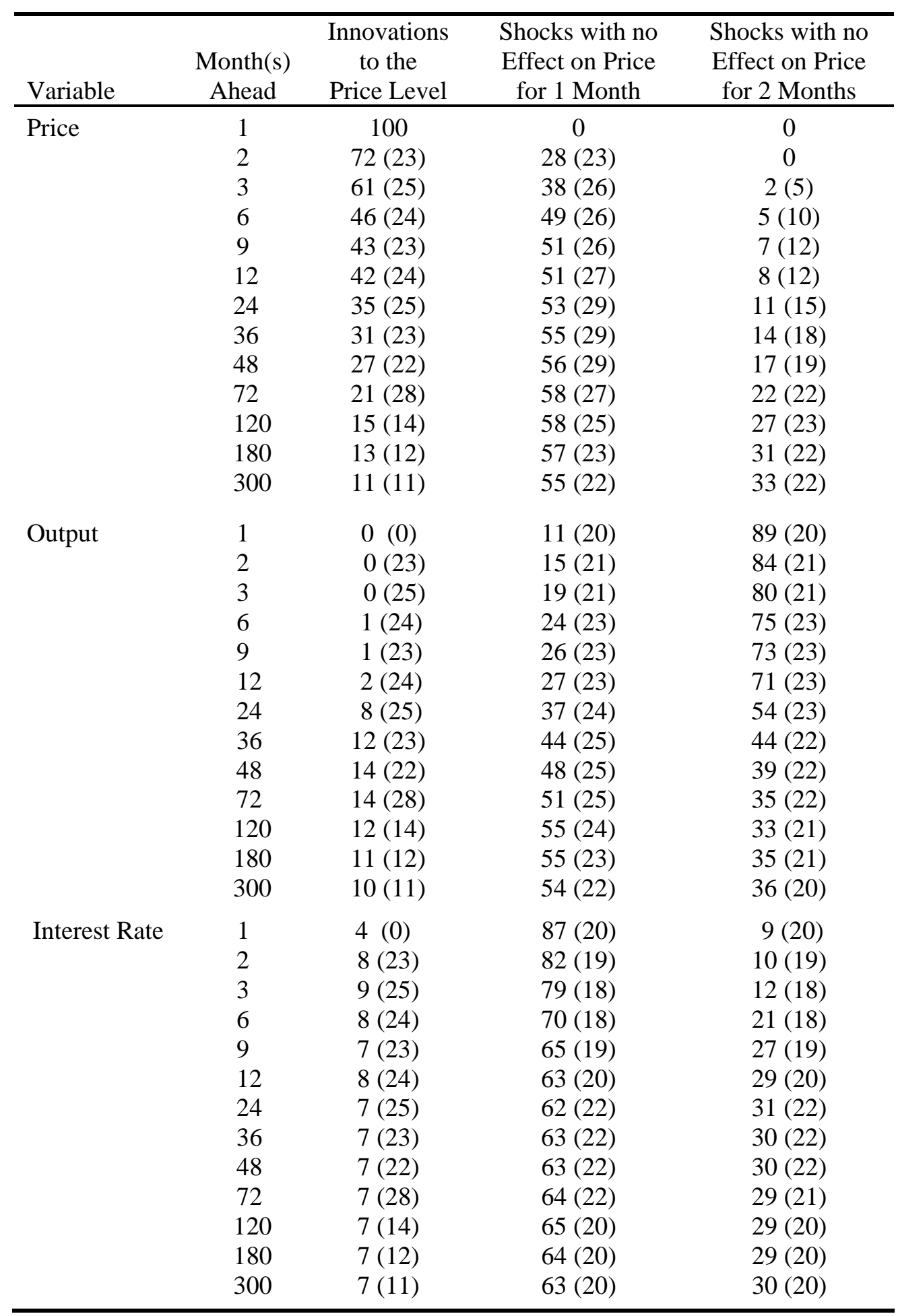

Standard errors are in parentheses. Some standard errors round to zero. 
Appendix: Specifications for the Bivariate Time Series Models with Monthly Data

\begin{tabular}{llllll}
\hline & \multicolumn{2}{c}{ Price and Output Series } & \multicolumn{3}{c}{ Lags } \\
\cline { 2 - 3 } \cline { 4 - 5 } Model Name & CPI Measure & IP Measure & Date & S & N \\
\hline Total IP & All Items & Total Index & $1947: 1$ & 16 & 38 \\
Trucks & New trucks & Light truck and utility vehicle & $1984: 1$ & 4 & 25 \\
Autos & New cars & Automobile & $1972: 1$ & 15 & 25 \\
Other Durables & House furnishings & Other durables goods & $1967: 1$ & 7 & 37 \\
Clothing & Apparel commodities & Clothing & $1947: 1$ & 8 & 25 \\
Energy & Energy commodities & Consumer Energy Products & $1967: 1$ & 5 & 26 \\
Food & Food & Food & $1972: 1$ & 2 & 25 \\
Tobacco & Tobacco and Smoking products & Tobacco & $1972: 1$ & 14 & 14 \\
Automotive Gas & Gasoline & Automotive gasoline & $1972: 1$ & 6 & 14 \\
Furniture & Furniture and bedding & Carpeting and furniture & $1970: 1$ & 5 & 25 \\
Beef & Beef and veal & Beef & $1972: 1$ & 4 & 25 \\
Pork & Pork & Pork & $1972: 1$ & 14 & 27 \\
Poultry & Poultry & Poultry processing & $1998: 1$ & 4 & 27 \\
Butter & Butter & Creamery butter & $1972: 1$ & 2 & 20 \\
Cheese & Cheese and related products & Cheese & $1978: 1$ & 3 & 14 \\
Dairy Products & Dairy and related products & Dairy product & $1989: 1$ & 2 & 26 \\
Beer & Beer and ale at home & Breweries & $1972: 1$ & 10 & 26 \\
Soft Drinks & Carbonated drinks & Soft drink and ice & $1978: 1$ & 5 & 25 \\
\hline
\end{tabular}

This appendix reports the Price and Output series used in each VAR Model, the starting Date for data used to estimate a VAR and the number of Lags in each model with $\mathrm{S}$ and $\mathrm{N}$ indicating the VAR with seasonally adjusted or not seasonally adjusted data, respectively. The lags were chosen by the Akaike Information Criterion. 


\section{Figure 1: Responses of GDP and GDP Deflator}

\section{to Price Innovation}
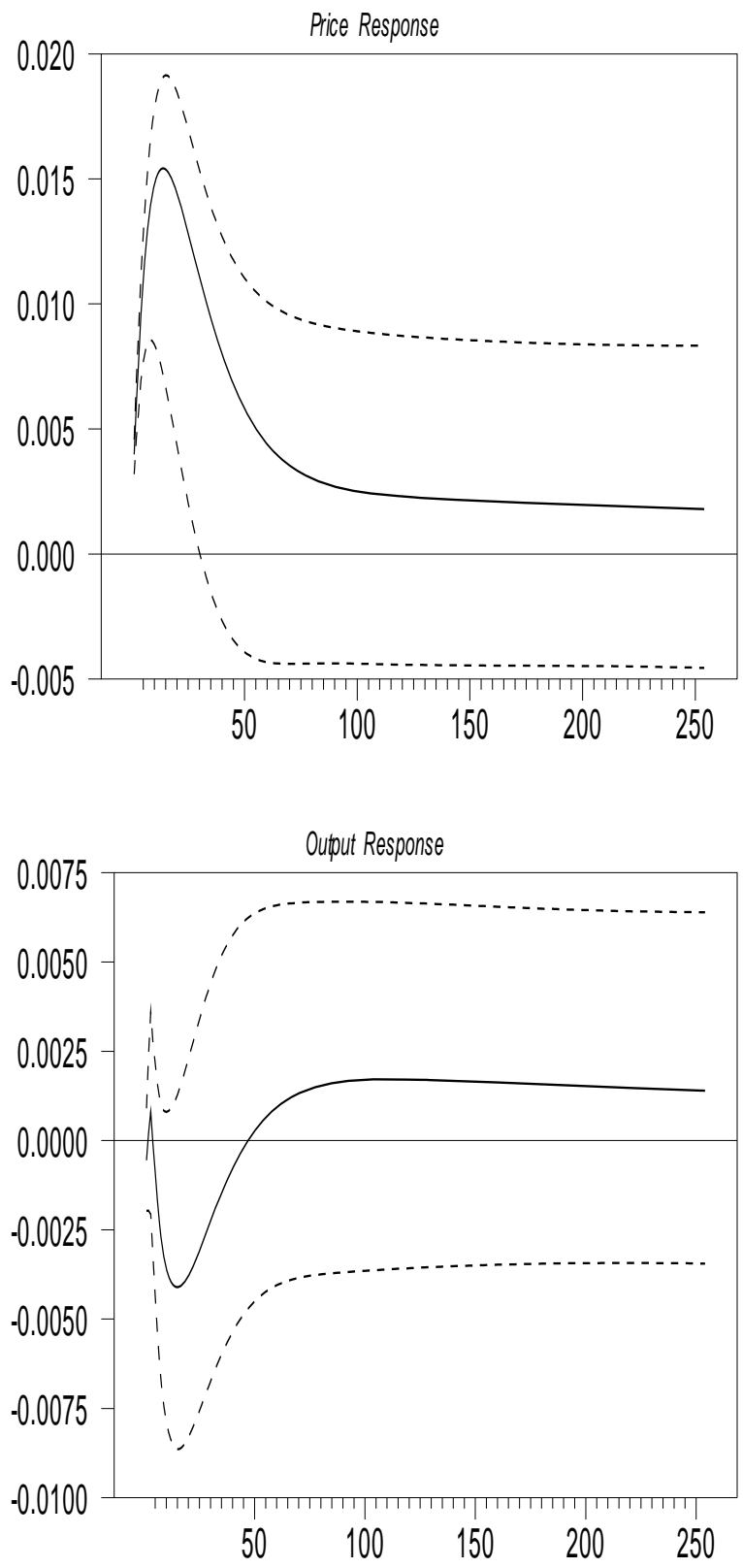

to Shock with No Effect on Price for 1 Quarter
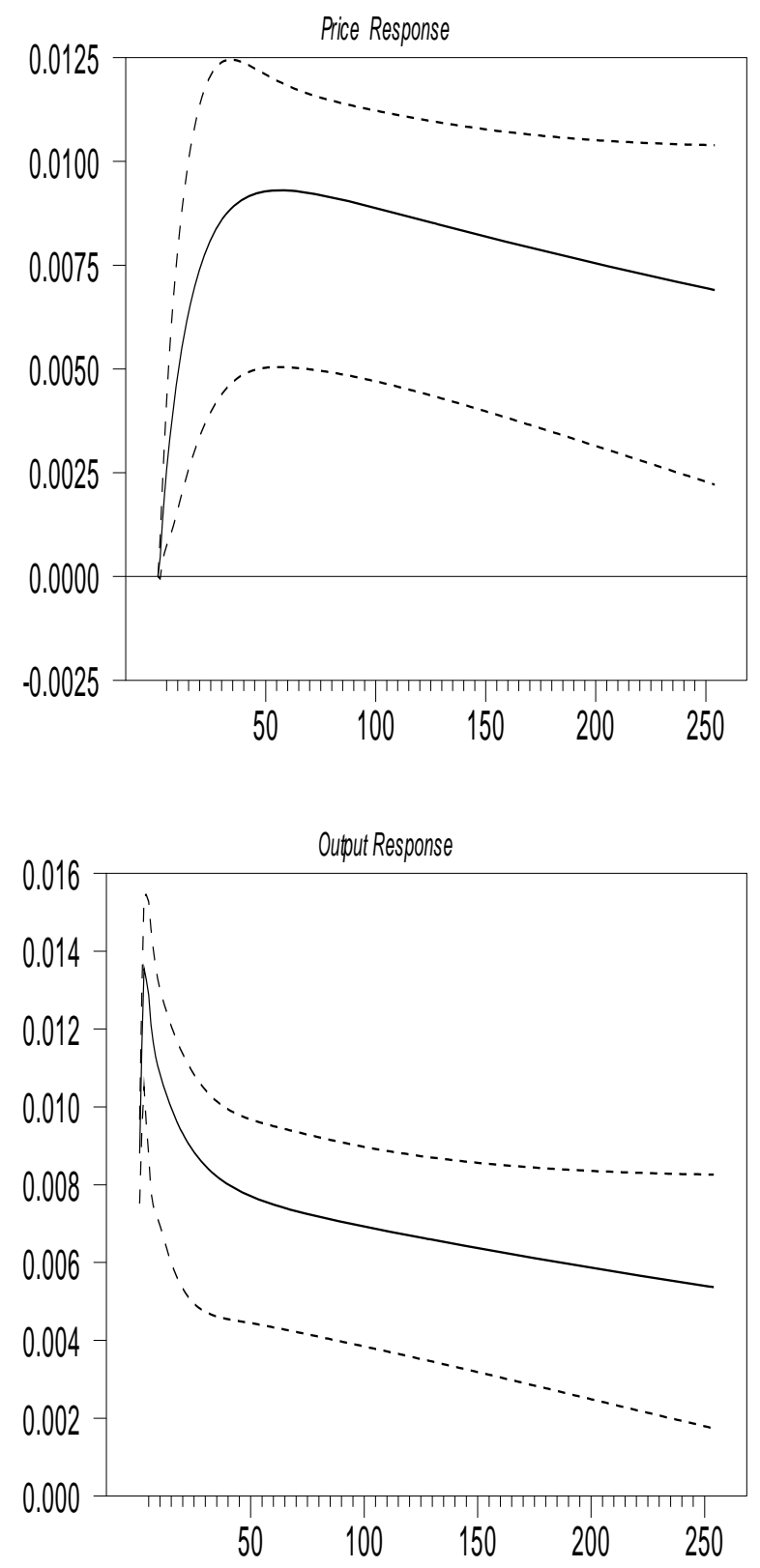
Figure 2: Responses of Total IP, and CPI All Items

to Price Innovation
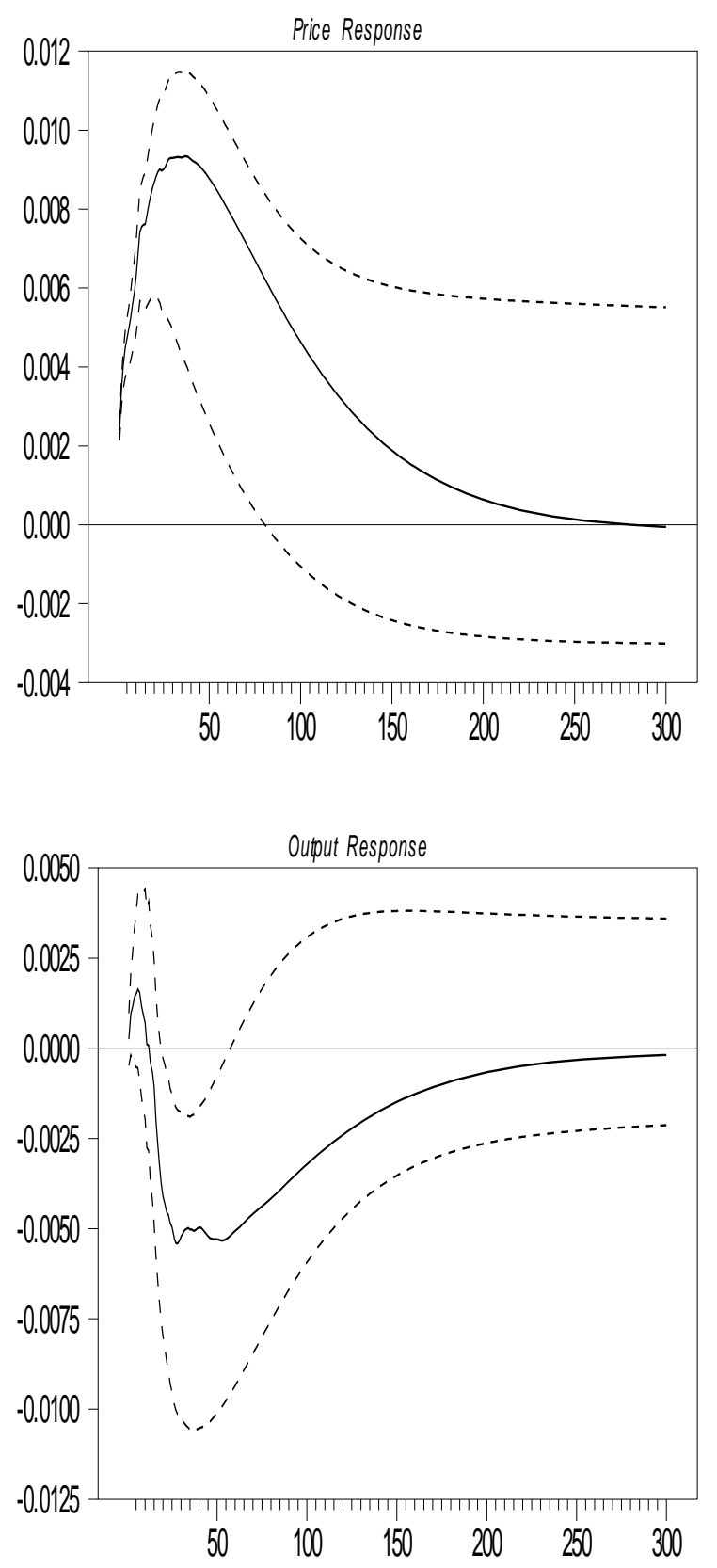

to Shock with No Effect on Price for 1 Month
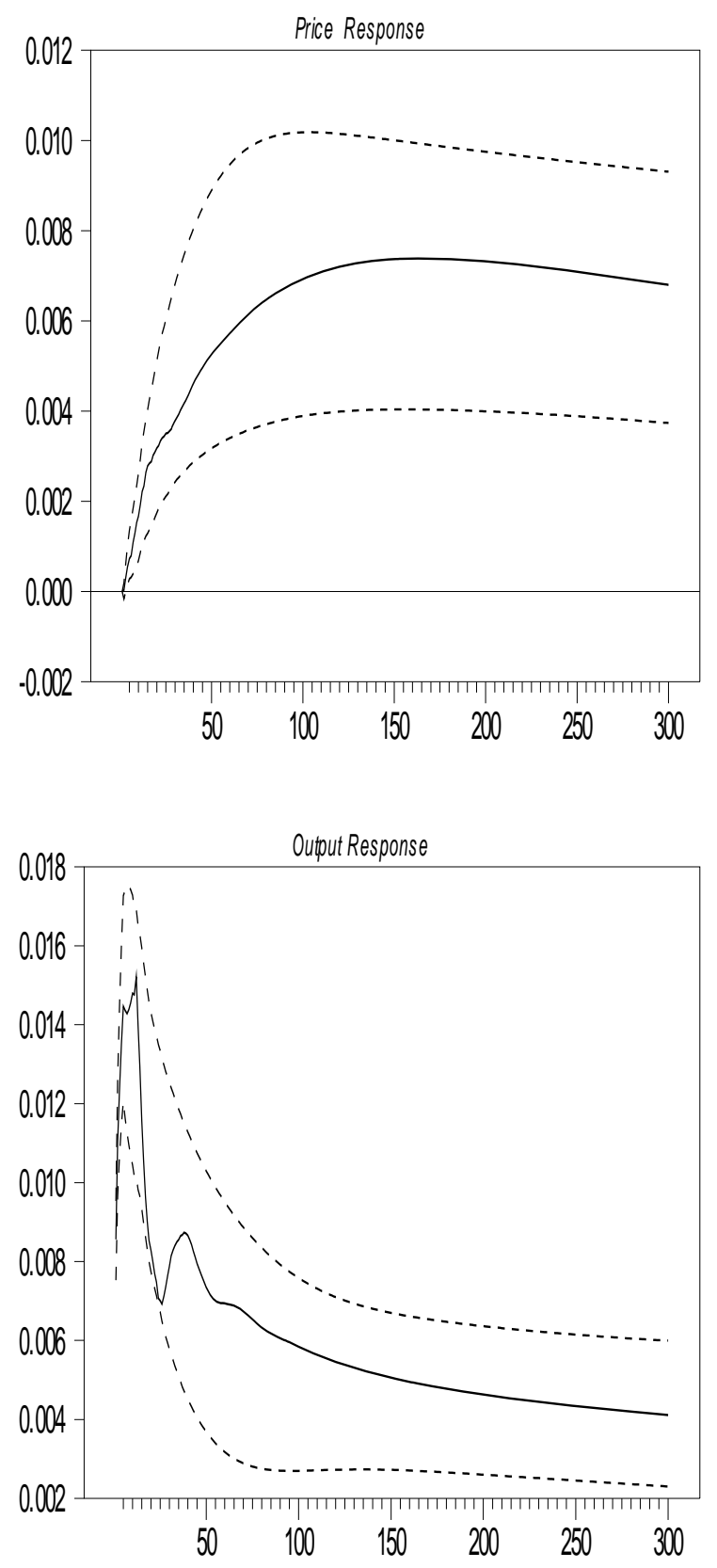